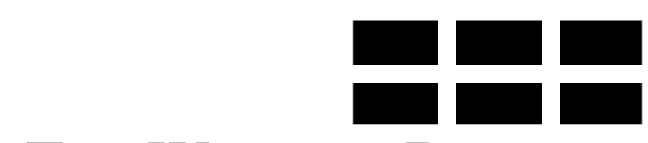

THE WILLIAM DAVIDSON INSTITUTE AT THE UNIVERSITY OF MICHIGAN BUSINESS SCHOOL

\title{
Impact of Cross-listing on Local Stock Returns: Case of Russian ADRs
}

\author{
By: Elena Smirnova
}

William Davidson Institute Working Paper Number 691 May 2004 


\title{
Impact of Cross-listing on Local Stock Returns: Case of Russian ADRs
}

\author{
Elena Smirnova (smirno2000@yahoo.com), \\ Baruch College and Graduate Center, City University of New York \\ Department of Economics and Finance \\ One Bernard Baruch Way, Box B10-225 \\ New York, NY, 10010 \\ Phone: 646-312-3456 \\ Fax: 646-312-3451
}

Keywords: finance, Russia, international cross-listings, ADRs

JEL classification:

\begin{abstract}
The paper examines the impact of American Depositary Receipt (ADR) listings on the return of the underlying Russian stocks.

The contribution of this paper is twofold. First, it looks at a new sample of ADRs issued by Russian companies. Second, the technique used to estimate the market model is different from the previous studies. The returns are modeled to follow GARCH process, as opposed to the regular OLS procedure, which assumes homoscedasticity in residual returns.

Average abnormal returns and cumulative average abnormal returns are calculated for the $[-25,+25]$ event window, with the ADR listing date being the event date. The results indicate a significant negative abnormal local market return on an ADR listing day.

The return volatilities after the listing are compared to those before the listing. Eleven out of sixteen companies experienced increased volatility of local returns after the cross-listing.
\end{abstract}




\section{INTRODUCTION}

Emerging capital markets in transition are often flawed by problems of low liquidity, insufficient regulation, fragility of institutions and weak minority shareholder protection. All these problems are relevant to the Russian stock market. The objective of this paper is to test the hypothesis of a beneficial cross-listing effect on the companies from a previously closed market. Theory suggests that stock prices from firms that cross-list from segmented markets with investment barriers are expected to rise, and their subsequent expected returns should fall as an additional built-in risk premium for these barriers disappears (Hargis and Ramanlal, 1998). Other factors driving the returns might be investor recognition and liquidity factors. Doidge, Karolyi and Stulz (2003) suggest an alternative explanation that has to do with the concentration of ownership. Controlling shareholders of firms listed in the US cannot extract as many private benefits from control compared to controlling shareholders of firms not listed in the US, and cross-listed firms are better able to take advantage of growth opportunities. Consequently, the cross-listed companies should be the ones whose interests are better aligned with those of minority shareholders. Better protection of minority shareholders of cross-listed companies might be another advantage of entering a foreign market.

This paper examines the local market reaction to the ADR issue by comparing returns and their variances before and after the listing date. Also the stock price reaction across the types of ADRs is compared, as each ADR program provides various degrees of liquidity and investor recognition with different disclosure requirements.

The paper is organized as follows. Part 1 provides a literature review. Part 2 describes the data and empirical methodology used in estimation of abnormal returns. Empirical results and conclusions are provided in Part 3.

\section{LITERATURE REVIEW}

An extensive body of literature deals with the valuation effects of cross-listing on the underlying stocks. When considering the effects of international cross-listing, the degree of integration between local and foreign markets plays an important role. The concern among policy makers in emerging markets is that cross-listing will divert order flow from their domestic markets to more developed foreign markets, lowering economic growth. Also, the more integrated global economy leads to increased possibility of contagion during a downturn. However, Karolyi (1996) provides evidence of the positive effect of globalization. He documents liquidity improvement, increase in total post-listing trading volume on 
average, and for many issues increase in home trading volume. Hargis (1997) and Smith and Sofianos (1997) find that cross-listing results in volume and liquidity improvement even though the foreign market dominates trading. Different authors find different causes of these effects. Domowitz, Glen and Madhavan (1998) argue that liquidity and volume effects depend on prior ownership restrictions across share classes, ownership restrictions across markets, and listing classifications. Karolyi (1996) attributes the liquidity improvement to the listing location, and the scope of foreign ownership restrictions in the home market. Hargis (1997) finds the total and home market volume of cross-listed shares is larger for the listings originating from emerging markets and depends on the ability of cross-listing to expand the international shareholder base.

One of the earliest papers related to the volatility effect is the paper by Jayaraman, Shastri and Tandon (1993), that looks at the case of ADR listings in the U.S. Jayaraman et al. use the sample of 95 firms that are registered abroad and had an ADR initially listed on US exchange over the period 1983 through 1988. The sample consists of ADRs from Japan, United Kingdom, Australia, France, Germany, Italy and Sweden. The authors find that the listing of ADRs is associated with a positive significant daily excess return of $0.47 \%$ on the underlying stock, which is primarily driven by the Japanese firms. One explanation is that the listing of ADRs provides the company with access to another capital market, thus allowing it to choose the lower cost source of capital. Comparison of variances of daily returns around the listing dates shows that the listing of ADRs is associated with an average increase of $55 \%$ in variance of returns. The result is consistent with information hypothesis of Freedman (1989), who suggests that crosslisting provides informed traders with additional opportunities to profit from their long-lived information.

The subsequent paper by Martell, Rodrigues and Webb (1999) examines the risk and return of 25 Latin American equity issues following the introduction of their ADRs in US equity markets in 1990 to 1994. Very few of the daily average excess returns are statistically significant. This suggests that the introduction of ADRs in New York does not have a significant impact on the underlying Latin American stocks. The study examines the cumulative average abnormal returns as well. There is a pattern of price increases in the two month period prior to ADR introduction, peaking at about seven trading days before the introduction. This is consistent with the literature on domestic listings, when price run-ups have been observed prior to domestic listing transfers. Also, there is a decrease in CAAR following an introduction: the CAAR between event days -1 and +25 is $-4.56 \%$, which is highly significant at $5 \%$ level. These patterns are consistent with the hypothesis of managerial timing. Managers select well performing stocks with a considerable investor interest for ADR listings. After the ADR introduction the stocks revert to a lower long-run level of performance. Impact on volatility of stock returns is studied comparing the variances of the stock returns before and after the introduction of ADRs. The authors are able to conclude that ADR introduction has no consistent impact on volatility. 
Lau, Diltz and Apilado (1994) examine valuation effects of international stock exchange listings of the U.S. companies. A sample of 346 listings by U.S. firms involving 8 countries from 1962 to 1990 is used. The data include U.S. stock listings on all major European, as well as Toronto and Tokyo stock exchanges. The study looks not only at the first trading day as the event date, but also at the firm's date of application for listing and date of acceptance of the application. In order to examine the returns for an 11day window surrounding three event days, the authors use the single-factor market model to generate abnormal returns.

For the 11 days surrounding a firm's date of application for listing, no significant abnormal returns are detected, with the exception of day -3 . Similarly, no significant single-day abnormal returns are detected in the 11 days surrounding the firm's date of acceptance for listing. The authors justify the absence of significance by the fact that the application and acceptance dates are rarely published in newspapers and are not widely known to investors. Thus, the absence of one-day abnormal returns may not necessarily imply that listings have no valuation consequences. A story is different for the first trading day. A statistically significant negative abnormal return is detected on that day. This suggests that the announcement of foreign stock listings is associated with a temporary negative valuation impact. There is also a significant negative cumulative average abnormal return over the interval $[-5,+3]$ days around the first trading day. This contradicts the results of a positive daily excess return found by Jayaraman et al. (1993) for foreign companies listing an ADR on US exchange. One explanation might be that listing on the US market provides access to lower cost source of capital, while cross-listing of American companies abroad does not benefit them in the same sense.

The authors compute the cumulative average abnormal returns for the 125-day post-listing period for the full sample and separately for each foreign stock exchange. Overall the findings reveal negative CAARs of $3.95 \%$ over the first 125 trading days. Trading on two of the ten exchanges, namely Tokyo and Basel, generates the negative returns. The result for Tokyo Stock Exchange may be explained by the maximum expansion of trading hours when the U.S. stock is traded there. This provides some support for the private information and / or noise trading hypotheses.

The study tests for the change in variability of the returns after the cross-listing, which is a proxy for the systematic risk of a company. For each firm in the sample an F-statistic is calculated. F-statistic frequencies appear to be fairly symmetrically distributed, implying that there is no clear pattern when comparing estimation period variances with event window variances. So, any abnormal returns found in the study are not caused by changes in the firm's systematic risk. The variance did not change significantly.

Miller (1999) tests for the different price response to cross-listings depending on the ADR type. He finds that foreign firms that list on NYSE or NASDAQ experience the largest stock price response. 
Average abnormal returns are smallest for the firms that dual list on PORTAL. This is consistent with superior liquidity and investor recognition hypotheses. Using a sample of 181 stocks that announced their first ADR program over the period from 1985 to 1995, Miller also reports a normal post-listing performance. Taken together these effects are consistent with the equilibrium models of asset pricing under barriers to capital flows. Share value increases and cost of capital declines as a result of listing. These results are also expected to hold for the sample of Russian stocks.

Podpiera (2001) extends the earlier model of Domowitz, Glen and Madhavan (1998) and estimates it using data on stocks from Central Europe (Czech Republic, Hungary and Poland) that are cross-listed on the London Stock Exchange. First, the paper uses the Granger causality framework and a cointegration/error correction to determine whether and to what extent the information flows between local and foreign markets are important. The markets appear to be fragmented, and the investors watch and react to the differences between the local and the London prices. The two time series of prices are cointegrated and estimation of an error correction model suggests that arbitrage works in all markets to correct any pricing errors. Granger causality is found to run in both directions, but the London market appears to be slightly more important.

Second, the author focuses on the return volatility of cross-listed stocks. According to the model, return variance of cross-listed securities on a partially fragmented market can be decomposed into three components. First is the base line volatility, which is determined by the realization of new information and market frictions unrelated to the following two factors. Second are the magnitude and characteristics of order flow (liquidity) and third is foreign market volatility. The first two factors were examined by Domowitz et al. (1998) using data on Mexican equities. The third factor is transferred to the local price of the cross-listed security through pricing errors and utilization of arbitrage opportunities by investors. Podpiera finds that for 7 out of 10 stocks volatility increased after the GDR listing.

Lowengrub and Melvin (2000) examine volume and volatility before and after international crosslisting using intraday data for the 23 German firms that issued ADRs between 1991 and 1997. The intraday volatility pattern became flatter after the cross-listing. Podpiera (2001) extends the earlier model of Domowitz et al. (1998) and estimates it using data on stocks from Central Europe (Czech Republic, Hungary and Poland) that are cross-listed on the London Stock Exchange. He finds that for 7 out of 10 stocks volatility increased after the GDR listing.

The results of the studies summarized above, though conflicting at times, point to one common finding. The degree of intermarket transparency matters a great deal in the subsequent price reaction of the underlying stock. Most cross-listings are made to avoid previous market segmentation and provide companies with the improved capital access. Strong information linkages between the two markets are 
beneficial. Overall, degree of information flows between domestic and foreign markets proves to be very important for the cross-listing effect.

The next section describes the Russian market for ADRs. One would expect a great degree of fragmentation with the US market due to strict restrictions on foreign activities prior to 1989.

\section{STOCK PRICE RESPONSE TO A DEPOSITARY PROGRAM}

\section{Sample Description: Russian ADRs}

The sample consists of 16 companies domiciled in Russia that announced their first ADR program over the period 1995 and 2001. The sample is constructed from the data compiled by the Bank of New York. Its web site (www.bankofnewyork.com/adr) provides a complete list of ADRs with the symbol, CUSIP, exchange, country, industry, and type of DR and effective date. There are 91 ADR issues from Russia. First requirement for a company to be included in the sample is the availability of local market price data. I matched the ADR list with the Datastream information on Russian companies. I was able to get local market closing daily prices for 30 firms that issued ADRs. Another requirement for a company to be included in the sample is the identifiable listing date. Following Martell, Rodriguez and Webb (1999), I chose the actual ADR introduction as opposed to an ADR announcement as the event date studied in this paper. The listing date marks the time when effects on the underlying stock can be realized through actual ADR trading. It appears that information revealed in the transactions matters more than the announcement of future trading opportunities. Besides, the regular methodology for getting announcement dates for cross-listed companies involves searching for the first news release on that matter. I used LEXIS-NEXIS to find announcements dates for the companies in my sample. Unfortunately, the results were conflicting, with some announcement dates being after the actual trading dates. Hence, I use the actual listing date as the event date in this paper. Listing dates were obtained from the Bank of New York database on ADRs.

Closing prices for each stock as well as the national market index are compiled from the Datastream International database. Each company is required to have return data at least 175 days before and 175 days after the listing date. This relatively small window is justified by availability of the local stock data. Only 20 firms had a window of this length. Since this paper looks at American Depositary Receipts, I eliminated 4 companies that issued off-shore Regulation S depositary receipts. Regulation S program allows raising capital through the placement of depositary receipts off-shore to non-US investors 
in reliance on Regulation S. Thus, the total sample size is sixteen companies that issued ADRs in the period from 1995 to 2001 .

Table 1 provides summary of the sample.

\section{Table 1. Types of ADRs.}

\begin{tabular}{cc}
\hline ADR type /Trading location & Number of firms \\
\hline Rule 144 / PORTAL & 1 \\
OTC pink sheets (Level 1) & 13 \\
NYSE (Level 2) & 2 \\
Total sample size: & 16 \\
\hline
\end{tabular}

Two of the Russian ADRs are traded on NYSE; thirteen are traded over the counter (Level 1), and one is rule 144A (privately placed). All of the depositary receipts in the sample are sponsored, i.e. issued with a formal agreement with a company. Level 1 ADR Program is the simplest way for companies to access the US capital markets. Level 1 ADRs are traded in the US over-the-counter (OTC) market with prices published in the "pink sheets". Issue of Level 1 ADR does not require full SEC registration and the company does not have to report its accounts under US Generally Accepted Accounting Principles (GAAP) or provide full SEC disclosure. Level 1 ADR program allows companies to enjoy the benefits of a publicly traded security without changing its current reporting process since it uses existing shares, and hence does not raise new capital. A cost of issue to the company is estimated to be less than $\$ 25,000$ (as reported by Miller, 1999, p.107). Generally, the majority of ADR issues are of Level 1 type. This holds for our sample (see table 2). Thirteen companies have issued Level 1 ADRs.

Sponsored Level 2 Depositary receipts are exchange-listed securities, but they do not raise new equity capital for a company. These ADRs require SEC registration and adherence to applicable requirements for US GAAP. The issue costs to a company vary from $\$ 200,000$ to $\$ 700,000$. Tatneft and Rostelecom are the only two companies in the sample who have listed their ADRs on the NYSE.

Privately placed (SEC Rule 144a ) Depositary receipts do not require SEC registration. Rule 144a programs provide for raising capital through the private placement of DRs with large institutional investors. Level 1 program can be established along side a Rule 144a program. These programs are rather costly: \$250,00-500,000 per issue. One company (Aeroflot) issued Rule 144a ADR. 
Table 2. Basic Characteristics of Cross Listed Stocks.

\begin{tabular}{|c|c|c|c|c|c|}
\hline & $\begin{array}{l}\text { Company } \\
\text { name }\end{array}$ & $\begin{array}{c}\text { Type of } \\
\text { issue }\end{array}$ & Industry & $\begin{array}{l}\text { Market Cap, } \\
\text { US\$ }\end{array}$ & Effective date \\
\hline 1. & Aeroflot & $144 a$ & Airlines & $388,175,845$ & Dec-22-2000 \\
\hline 2 & AO Mosenergo & Level 1 & Utility - Gas and Electric & $1,201,378,963$ & July-17-1997 \\
\hline 3 & AO Surgutneftegas & Level 1 & Oil and Gas -Service & $11,546,646,965$ & Dec-30-1996 \\
\hline 4 & Bank Vozrozhdeniye & Level 1 & Banking & $41,000,705$ & July-03-1996 \\
\hline 5 & Chernogorneft & Level 1 & Oil and Gas-Service & $66,927,505$ & Mar-01-1996 \\
\hline 6 & Irkutskenergo & Level 1 & Utility - Gas and Electric & $383,251,379$ & Jan-23-1997 \\
\hline 7 & Samaraenergo & Level 1 & Utility - Gas and Electric & $119,233,240$ & Feb-09-1998 \\
\hline 8 & Lukoil & Level 1 & Oil and Gas-Service & $12,183,889,751$ & Dec-01-1995 \\
\hline 9 & $\begin{array}{l}\text { Moscow City Telephone } \\
\text { Network }\end{array}$ & Level 1 & Telecom - Data Networking & $578,760,241$ & June-21-99 \\
\hline 10 & Norilsk Nickel & Level 1 & Mining and Minerals & $3,162,888,660$ & June-15-01 \\
\hline 11 & Rostelecom & Level 2 & Telecom-Data Networking & $847,716,344$ & Feb-12-1998 \\
\hline 12 & Seversky Tube Works & Level 1 & Steel & $33,690,300$ & Feb $-01-01$ \\
\hline 13 & Sibneft & Level 1 & Oil and Gas - Service & $4,443,071,293$ & Apr-20-1999 \\
\hline 14 & Tatneft & Level 2 & Oil and Gas - Service & $1,105,685,429$ & Mar-25-1998 \\
\hline 15 & TSUM & Level 1 & Household Prod-Appliances & $30,483,380$ & July-03-1997 \\
\hline 16 & GUM & Level 1 & Retailing & $93,000,006$ & June-07-96 \\
\hline
\end{tabular}

The following section describes the methodology of this study.

\section{Empirical Method}

An event study procedure is used to measure changes in share value around the listing date. Local returns are computed as follows:

$$
\mathrm{R}_{\mathrm{t}}=\ln \left(\mathrm{P}_{\mathrm{t}}\right)-\ln \left(\mathrm{P}_{\mathrm{t}-1}\right) \text {, }
$$

where $\mathrm{P}_{\mathrm{t}}$ is daily closing price.

To measure abnormal return I estimate a market model for each firm using local stock returns denominated in U.S. dollars. With the listing date defined as day 0 , the market coefficients are estimated in the pre-listing period: day -175 to day -26 . The next section describes the market model in detail.

Following the technique used by Jayaraman, Shastri and Tandon (1993), 51 days around listing are excluded to allow for a permanent effect. It is typical for the estimation and the event windows not to overlap, as noted by Campbell et al. (1997, p. 158). This design provides the estimators for the parameters of the normal return model that are not influenced by the event-related returns. Including the event window in the estimation of the parameters of the market model could lead to the event returns having a large influence on normal return measure. In this situation both the normal and abnormal returns would reflect the impact of the cross-listing. This will be problematic since the methodology implicitly assumes 
that the event is exogenous with respect to the change in market value of the security. Figure 1 shows the non-overlapping windows.

\section{Figure 1. Time Line for the Cross-listing Study}

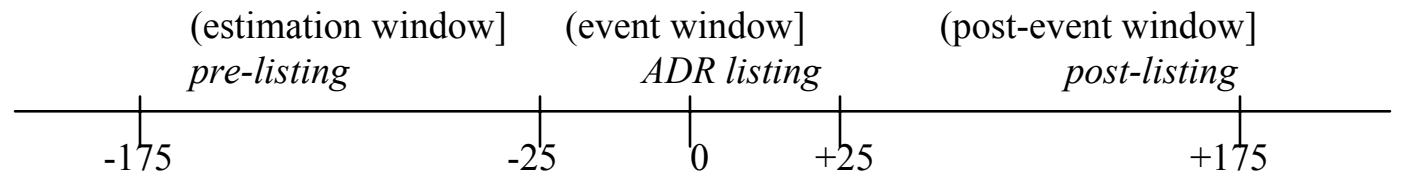

Abnormal returns in the event window are determined by the prediction errors from the market model. Coefficients from the pre-listing model are used to calculate abnormal returns from day -25 to day +25 . Abnormal returns are then averaged across firms (average abnormal returns) and across time (cumulative abnormal returns).

\section{Market Model Specification}

Stock returns are modeled using the GARCH and ARCH-in-mean specification. Finance theory suggests that an asset with a higher perceived risk would on average pay a higher return. If we decompose the difference of ex-post return and the risk-free rate into the unanticipated mean component and unanticipated error component, then the theory suggests that mean return is a function of variance, and the residual return can be modeled as ARCH-in-mean process.

The presence of heteroscedasticity in residual returns, if not properly explicitly accounted for, leads to inefficient parameter estimates as well as biased and inconsistent test statistics in many estimated assetpricing models. Moreover, as noted by Giacotto and Ali (1982), standard event studies testing for the effects of firm-specific events on security prices must be modified if heteroscedasticity is present. Finally, Diebold, Lim and Lee (1992) state that because excess unconditional kurtosis may be unrelated to conditional heteroscedasticity, examining time-varying volatility may shed light on the non-normality of stock returns, as well as on convergence to normality under temporal aggregation. 
In a GARCH model the conditional variance of market model residual returns is permitted to move in autoregressive fashion. The model follows the one introduced by Diebold et al. (1992). A market model with $p$ th and $q$ th order GARCH disturbances for a particular firm $i$ is written as:

$$
\begin{aligned}
& \mathrm{R}_{\mathrm{t}}{ }^{\mathrm{i}}=\mathrm{X}_{\mathrm{t}}{ }^{\mathrm{i}} \beta^{\mathrm{i}}+\varepsilon_{\mathrm{t}}{ }^{\mathrm{i}}, \\
& \varepsilon_{\mathrm{t}}{ }^{\mathrm{i}} \mid \Omega_{\mathrm{t}-1}{ }^{\mathrm{i}} \sim N\left(0, h_{t}{ }^{i}\right)
\end{aligned}
$$

where $h_{t}{ }^{i}=\alpha_{0}{ }^{i}+\sum_{j} \alpha_{j}{ }^{i}\left(\varepsilon_{t-j}{ }^{i}\right)^{2}++\sum_{k} \gamma_{k}{ }^{i}\left(h_{t-k}\right)$ is conditional variance of the error term,

$\alpha_{0}{ }^{\mathrm{i}}>0, \quad \alpha_{\mathrm{t}}{ }^{\mathrm{i}}>=0, \quad j=1, \ldots, q ; \quad k=1, \ldots, p$.

$\mathrm{R}_{\mathrm{t}}{ }^{\mathrm{i}}$ is the return on the stock of firm $i$ at time $t$ (in US dollars);

$\Omega_{\mathrm{t}-1}{ }^{\mathrm{i}}$ is the information set that contains $\varepsilon_{\mathrm{t}-1}{ }^{\mathrm{i}}, \varepsilon_{\mathrm{t}-2}{ }^{\mathrm{i}}, \ldots, \varepsilon_{\mathrm{t}-\mathrm{p}}{ }^{\mathrm{i}}$; and $\mathrm{t}=1, \ldots, \mathrm{T}$ indexes time.

The row vector $\mathrm{X}_{\mathrm{t}}{ }^{\mathrm{i}}$ contains an intercept, the local market index return and the US market index return. ${ }^{1}$

The Russian market index closing prices are taken from Datastream International, which quotes them in U.S. dollars. The S\&P 500 composite index return is used as a proxy for US market return. The US return data are obtained from the CRSP database.

First, I implement Lagrange multiplier (LM) and Portmanteau Q tests to check for heteroscedasticity in the returns. The results indicate that the returns exhibit heteroscedasticity.

The AUTOREG procedure in SAS is used to test, first, for the number of lagged error terms $(q)$ in the variance of error term, and second, whether unconditional variance depends on the previous variances ( $p$ order). Most of the companies' returns exhibit GARCH $(1,1)$ process.

The daily abnormal return for security $i$ for day $t, \mathrm{AR}_{\text {it, }}$, is calculated as:

$\mathrm{AR}_{\text {it }}=\mathrm{R}_{\mathrm{it}}-\left(\mathrm{X}_{\mathrm{t}}{ }^{\mathrm{i}} \beta^{\mathrm{i}}\right)$,

where $\beta^{i}$ is the vector of the estimated intercept and the coefficients for local market and US market proxies from the market model (equation 2).

The daily abnormal returns are then averaged across $\mathrm{N}$ securities, weighted by companies' size, on day $\mathrm{t}$ to compute the average abnormal return:

$$
\mathrm{AR}_{\mathrm{t}}=\Sigma_{\mathrm{i}}\left(\mathrm{AR}_{\mathrm{it}} \mathrm{W}_{\mathrm{i}}\right) \text {, }
$$

where $\mathrm{w}_{\mathrm{i}}=$ MarketCap $_{\mathrm{i}} / \Sigma_{\mathrm{i}}\left(\right.$ MarketCap $\left._{\mathrm{i}}\right)$ is the weight of each company, based on its market capitalization in US dollars.

To judge the statistical significance of the abnormal returns, the Dodd and Warner (1983) methodology was then used to compute standardized abnormal returns and their test statistics. For each

\footnotetext{
${ }^{1}$ If the markets are not completely segmented, the firm's shares may be priced with respect to its home market as well as the market where it dual lists (Stapleton and Subrahmanyam (1977), Miller (1999)). Predicted returns are determined from the multivariate regression of the domestic market proxy and the S\&P500 index.
} 
security $i$, the daily abnormal return $\mathrm{AR}_{\mathrm{it}}$ is standardized by the square root of its estimated forecast variance to determine its standardized abnormal return:

$$
\mathrm{SAR}_{\mathrm{it}}=\mathrm{AR}_{\mathrm{it}} / \mathrm{s}_{\mathrm{it}}
$$

where:

$\mathrm{s}_{\mathrm{it}}=\left\{\mathrm{s}_{\mathrm{i}}^{2}\left[1+1 / \mathrm{L}+\left(\mathrm{R}_{\mathrm{mt}}-\mathrm{R}_{\mathrm{m}}^{\prime}\right)\left(\mathrm{R}_{\mathrm{ust}}-\mathrm{R}_{\text {us }}^{\prime}\right) / \Sigma_{\mathrm{k}=1}^{\mathrm{L}}\left(\mathrm{R}_{\mathrm{mk}}-\mathrm{R}_{\mathrm{m}}^{\prime}\right)\left(\mathrm{R}_{\mathrm{usk}}-\mathrm{R}_{\mathrm{us}}^{\prime}\right)\right]\right\}^{1 / 2}$

where $\mathrm{s}_{\mathrm{i}}{ }^{2}$ is the estimated residual variance from the market model regression for security $i, \mathrm{R}_{\mathrm{mt}}$ is the local market return on day $t, R_{u s t}$ is the US market return on day $t, R_{m}^{\prime}$ is the mean local market return over the $\mathrm{L}$ days used to estimate the regression, $\mathrm{R}_{\text {us }}{ }$ is the mean return on the US market index over the $\mathrm{L}$ days used to estimate the regression. For each day $t$ of the event period, a test statistic $Z_{t}$ is calculated:

$$
\mathrm{Z}_{\mathrm{t}}=\sum_{\mathrm{i}=1}{ }^{\mathrm{N}} \operatorname{SAR}_{\mathrm{it}}(1 / \mathrm{N})^{1 / 2}
$$

Cumulative average abnormal returns were calculated as follows:

$$
\mathrm{CAR}_{\mathrm{t}, \mathrm{T}}=\Sigma_{\mathrm{t}=1}^{\mathrm{T}} \mathrm{AR}_{\mathrm{t}}
$$

where $\mathrm{T}$ is the number of days in the accumulation period. Cumulative test statistics are calculated as follows:

$$
\mathrm{CZ}_{\mathrm{t}}=\sum_{\mathrm{i}=1}^{\mathrm{T}} \mathrm{Z}_{\mathrm{t}}(1 / \mathrm{T})^{1 / 2}
$$

The event window extends from 25 days prior to the event day to 25 days after the event day. Number of days in the market regression is $150(\mathrm{~L}=150)$.

\section{RESULTS}

On the listing day, day 0 , the local market exhibits negative statistically significant average abnormal return of $1.045 \%$. Table 3 presents the daily average abnormal returns $\left(\mathrm{AR}_{\mathrm{it}}\right)$, and the cumulative abnormal returns for day -25 through day +25 around the listing date. This result is similar to that of Lau, Diltz and Apilado (1994), who found temporary negative valuation impact on the first trading date for the sample of US companies listing abroad. The authors also found a significant negative cumulative average abnormal return over the interval $[-5,+3]$ days around the first trading day. This contradicts the results of a positive daily excess return found by Jayaraman et al. (1993) for foreign companies listing an ADR on US exchange. 
Table 3. Average Abnormal Returns (AAR ${ }_{t, T}$ ), Cumulative Abnormal Returns (CAR $\mathrm{C}_{\mathrm{t}, \mathrm{T}}$ ) and the percentage of firms with nonnegative abnormal returns.

** indicates significance at $5 \% ; *$ indicates significance at $10 \%$.

\begin{tabular}{ccc}
\hline AAR $_{\mathrm{t}, \mathrm{T}}$ & $\mathrm{CAR}_{\mathrm{t}, \mathrm{T}}$ & Days \\
\hline$-0.0084369^{* *}$ & -0.00844 & -25 \\
-0.0010037 & -0.04869 & -20 \\
0.0029113 & -0.06068 & -15 \\
-0.0076629 & -0.10726 & -10 \\
-0.0011306 & -0.13826 & -5 \\
0.0518202 & -0.12195 & -2 \\
$-0.011274^{* *}$ & -0.13322 & -1 \\
$-0.0104517^{* *}$ & -0.14368 & 0 \\
$-0.0193449^{* *}$ & -0.16302 & 1 \\
$-0.012365^{* *}$ & -0.17539 & 2 \\
$-0.0327492^{* *}$ & -0.19012 & 5 \\
-0.0072274 & -0.12569 & 10 \\
-0.0027633 & -0.15288 & 15 \\
-0.0019355 & -0.19347 & 20 \\
-0.0035263 & -0.19878 & 25 \\
\hline
\end{tabular}

Most of the cumulative abnormal returns are negative, but statistically insignificant. This is consistent with a normal post-listing performance documented by Miller (1999). Figure 2 presents cumulative abnormal returns in the event window.

Figure 2. Cumulative abnormal returns from day -25 before to day +25 after the listing of an American Depositary Receipt program. The daily abnormal returns are averaged across firms and then cumulated. The sample includes 16 companies.

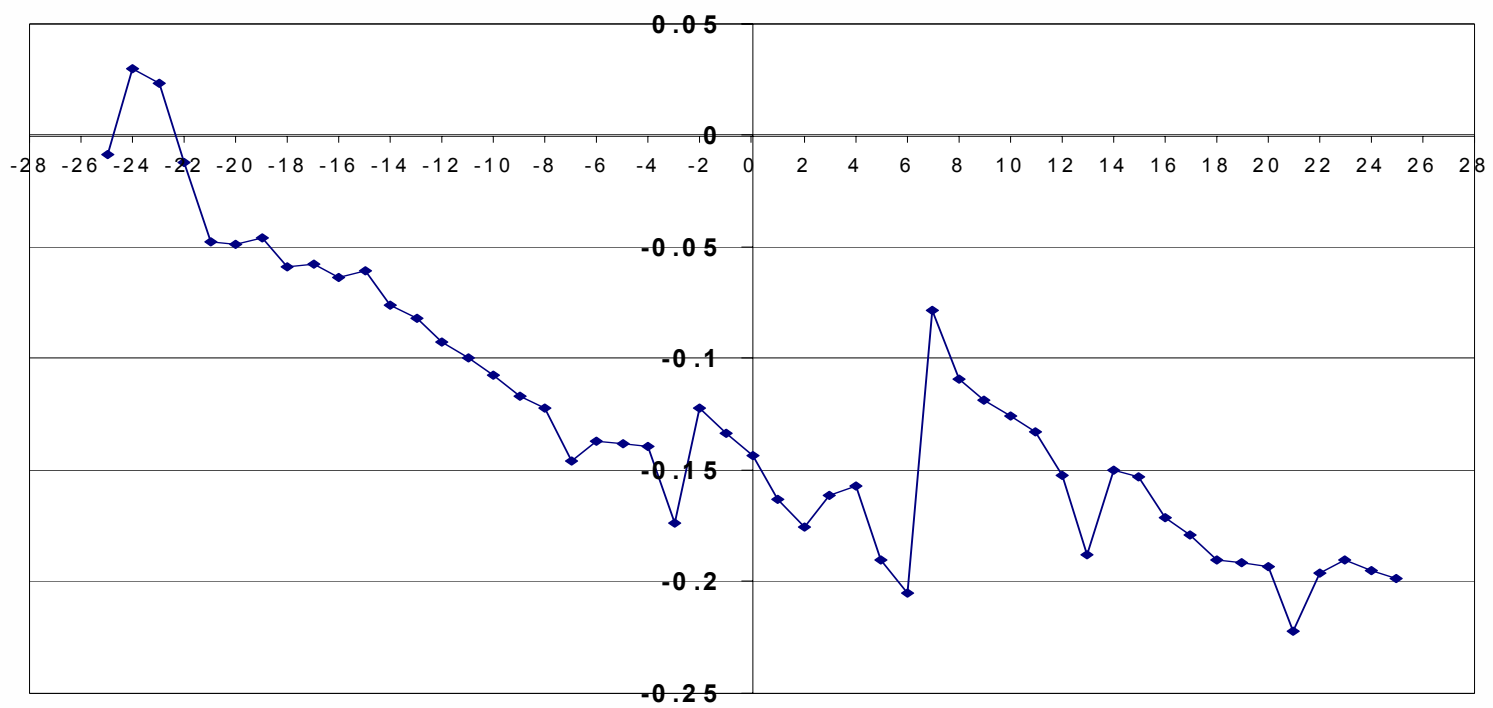


This finding contradicts the hypothesis of beneficial cross-listing effect for the stocks from developing markets. When the data becomes available, it would be interesting to check the long-run performance of dually listed Russian stocks after the listing.

Table 4 presents average abnormal returns around the listing by the ADR type. Russian companies that list ADRs over the counter as pink sheets experience the least negative stock response in the local market. Consistent with Miller's (1999) findings, NYSE cross-listing provides the favorable significant response from the local investors.

Table 4. Average abnormal returns around the listing of ADR by equity offering type. ** significant at $5 \%$.

\begin{tabular}{lccc}
\hline \multicolumn{1}{c}{ ADR type } & $\mathrm{t}=-25$ to -2 & $\mathrm{t}=-1$ to +1 & $\mathrm{t}=+2$ to +25 \\
\hline Rule 144 / PORTAL & -0.00799 & -0.05371 & -0.14718 \\
OTC pink sheets (Level 1) & 0.04758 & -0.00937 & 0.04996 \\
NYSE (Level 2) & $0.00578^{* *}$ & -0.05726 & -0.05053 \\
$\quad$ Total sample & 0.04546 & -0.12028 & -0.14775 \\
\hline
\end{tabular}

These results are most likely related to the costs of ADR issue. The least costly pink sheets Level 1 ADRs provided the most favorable local market response. This is a puzzling result, since liquidity and investor recognition hypothesis would predict that firms that list on PORTAL as Level 1 ADRs would get low investor awareness and the smallest price response (Miller, 1999). The result might be attributed to the fact that local investors are seeking for the cheapest ways to access overseas markets, trying to keep issuing costs down.

Next I compare the volatilities of stock returns before and after the ADR listing. The window used for the before period is $[-175 ;-26]$ days, and $[+26 ;+175]$ days for the after period. Variance ratios are computed as:

$$
\text { Ratio }=(\text { VAR after }) /(\text { VAR before })
$$

Thus, if the ratio is greater than one, the variability of stock returns increased after the ADR introduction, and vice versa.

Table 5 shows the variance ratios for the sample companies. Eleven of the ratios are greater than one, and ten of them are statistically significant based on an F-ratio test of whether the variance ratio is equal to one. That means that most of the companies in the sample experienced a greater volatility of returns after the ADR listing. Five firms have variance ratios less than one. Four of these ratios are statistically significant at the $5 \%$ level of confidence, implying that return variance for the four companies in the sample reduced after the listing. 
The return volatilities did not change consistently for the whole sample, with most companies experiencing an increase in volatility of local stock returns. The result can be attributed to low degree of information transparency between the local and the US markets.

Table 5. Variance Ratios. Ratios are comparing variance after the listing to variance before the listing. Before period includes $[-175,-26]$ days before the listing. After period includes $[+26,+175]$ days after the listing.

** indicates significance at 5\%; * indicates significance at $10 \%$.

\begin{tabular}{llcc}
\hline & \multicolumn{1}{c}{$\begin{array}{c}\text { Company } \\
\text { name }\end{array}$} & Type of issue & Variance ratio \\
\hline 1. & Aeroflot & $144 \mathrm{a}$ & 1.141994 \\
2 & AO Mosenergo & Level 1 & $1.823032^{* *}$ \\
3 & AO Surgutneftegas & Level 1 & $0.063245^{* *}$ \\
4 & Bank Vozrozhdeniye & Level 1 & $5.77629^{* *}$ \\
5 & Chernogorneft & Level 1 & $16.306834^{* *}$ \\
6 & Irkutskenergo & Level 1 & $0.226385^{* *}$ \\
7 & Samaraenergo & Level 1 & $8.685847^{* *}$ \\
8 & Lukoil & Level 1 & $0.074944^{* *}$ \\
9 & Moscow City Telephone Network & Level 1 & 0.838374 \\
10 & Norilsk Nickel & Level 1 & $4.106529^{* *}$ \\
11 & Rostelecom & Level 2 & $2.008565^{* *}$ \\
12 & Seversky Tube Works & Level 1 & $2.096824^{* *}$ \\
13 & Sibneft & Level 1 & $0.085432^{* *}$ \\
14 & Tatneft & Level 2 & $4.939007^{* *}$ \\
15 & TSUM & Level 1 & $1.963676^{* *}$ \\
16 & GUM & Level 1 & $5.598065^{* *}$ \\
\hline
\end{tabular}

Number of ratios greater than one:

Number of ratios less than one:

11

5 


\section{CONCLUSIONS}

This paper has investigated the local market response to the listing abroad. Empirical evidence on the effects of international cross listing on the underlying stocks is mixed. The findings presented here indicate that conditions under which ADR introductions from emerging markets affect the underlying stock are also not well clarified.

Using a traditional event study methodology with a modified covariance structure of returns the paper has tested the hypothesis of beneficial cross listing effect on companies from Russia. Available data relating to stock prices in developing countries, and particular in transition economies, are subject to shortcomings. The paper used most recent sources, which are believed to be generally comparable. The results of the research, however, have to be interpreted cautiously. In general, empirical evidence provides no support to the hypothesis of favorable market reaction to a listing of ADR. Significant negative abnormal return was found on the day of ADR listing. This finding however is consistent with the paper of Lau et al (1994), who used a sample of US companies listing abroad. Overall, the results of this study do not support investor recognition and liquidity hypothesis. ADR issue by Russian companies did not earn positive abnormal return on the listing date. One of possible explanations may be the incorrect choice of event window. Since the data on announcement day of ADR listing was unreliable, this paper used listing day with 175 days around it. The market beta may be overestimated because local stock returns might have been risen after the announcement day and abnormal return may be underestimated (see equation 3).

When considering variance of returns after the cross listing, the results indicate increased variance of returns for most companies in the sample. ADR listing provides greater transparency and awareness of the company abroad, with more trades being executed in both markets. The result of increased variance is consistent with Freedman's (1989) private information hypothesis: an increase in variance is connected to more private information acquired by informed traders after the cross listing. ${ }^{2}$

Since this paper intended to take a first look at the issue of interest it could not take into account many aspects that were beyond the scope of research. A further investigation of the cross listing effects will be possible when a comparable and complete data sources are provided by companies and statistical offices in the transforming countries.

\footnotetext{
${ }^{2}$ Freedman (1989) examines the impact of allowing informed traders to optimally allocate their trading of a cross-listed stock between the foreign and domestic markets. The model allows for a long-lived private information by assuming a two-period structure. Cross listing provides informed traders with additional opportunities to profit from their long-lived information. The cross listing causes the variance of returns in the domestic exchange to increase regardless of the number of informed traders or liquidity traders. It results in more information being revealed.
} 


\section{REFERENCES}

Black F. (1986). Noise. Journal of Finance 41, 529-543.

Campbell, Andrew and MacKinlay (1997). The Econometrics of Financial Markets. Princeton University Press.

Diebold, Lim, Lee (1992). A note on conditional heteroscedasticity in the market model. Journal of Accounting, Auditing, and Finance, vol. 12, p.141-150.

Doidge C., Karolyi A., and Stulz R., 2004. Why are foreign firms listed in the U.S. worth more? Journal of Financial Economics, vol. 71, p. 205-238.

Domowitz, Glen and Madhavan (1998). International cross listing and order flow migration: evidence from an emerging market. Journal of Finance, 2001-2027.

Dodd and Warner (1983). On corporate governance: A study of proxy contests. Journal of Financial Economics 11, April 1983, 401-438.

Freedman, R. (1989). A theory of the impact of international cross listing. Working paper. Stanford University.

French and Roll (1986). Stock return variances: The arrival of information and the reaction of traders. Journal of Financial Economics 17, 5-26.

Garbade and Silber (1977). Dominant and Satellite Markets: A Study of Dually Traded Securities. Review of Economics and Statistics, Vol.25, pp.455-461.

Giacotto and Ali (1982). Optimal distribution-free tests and further evidence of heteroscedasticity in the market model. Journal of Finance, vol. 37.

Hamilton (1994). Time Series Analysis. Princeton University Press.

Hargis, K. (1997). When does multimarket trading improve the quality of the primary market? Evidence from the international cross-listings. Working paper. Goldman Sachs and Co.

Hargis and Ramanlal (1998). When does internationalization enhance the development of domestic stock market? Journal of Financial Intermediation, no. 7.

Jayaraman, Shastri and Tandon (1993). The impact of international cross-listings on risk and return: the evidence from ADRs. Journal of Banking and Finance. 91-103.

Karolyi (1996). What happens to stocks that list shares abroad? A Survey of the evidence and its managerial implications. University of Western Ontario Working paper.

Lau, Diltz and Apilado (1994). Valuation effects of international stock exchange listings. Journal of banking and Finance, no. 18, 743-755.

Lieberman, Ben-Zion and Hauser (1999). A Characterization of the Price Behavior of International Dual Stocks: An Error Correction Approach. Journal of International Money and Finance 18, pp.289304.

Lowengrub and Melvin (2000). Before and After International Cross-Listing: An intraday examination of volume and volatility. Arizona State University, Working Paper.

Martell, Rodriquez and Webb (1999). The impact of listing of ADRs on the risks and returns of the underlying shares. Global Finance Journal 10:2, 147-160.

Miller, D.P. (1999). The market reaction to international cross-listings: evidence from depositary Receipts. Journal of Financial Economics 51, 103-123.

Podpiera (2001). International Cross Listing: The effects of market fragmentation and information flows. February. Academy of Science of the Czech Republic, Working paper.

Smith and Sofianos (1997). The impact of NYSE listing on the global trading on non-US stocks. NYSE working paper \# 97-02.

Stapleton and Subrahmanyam (1977). Market imperfections, capital market equilibrium and corporate finance. Journal of Finance 32, 307-319. 


\section{DAVIDSON INSTITUTE WORKING PAPER SERIES - Most Recent Papers}

The entire Working Paper Series may be downloaded free of charge at: www.wdi.bus.umich.edu

CURRENT AS OF 5/09/04

\begin{tabular}{|c|c|c|}
\hline Publication & Authors & Date \\
\hline $\begin{array}{l}\text { No. 691: Impact of Cross-listing on Local Stock Returns: Case of } \\
\text { Russian ADRs }\end{array}$ & Elena Smirnova & May 2004 \\
\hline $\begin{array}{l}\text { No. 690: Executive Compensation, Firm Performance, and State } \\
\text { Ownership in China:Evidence from New Panel Data }\end{array}$ & Takao Kato and Cheryl Long & May 2004 \\
\hline $\begin{array}{l}\text { No. 689: Diverging Paths: Transition in the Presence of the Informal } \\
\text { Sector }\end{array}$ & Maxim Bouev & May 2004 \\
\hline $\begin{array}{l}\text { No. 688: What Causes Bank Asset Substitution in Kazakhstan? } \\
\text { Explaining Currency Substitution in a Transition Economy }\end{array}$ & Sharon Eicher & May 2004 \\
\hline $\begin{array}{l}\text { No. 687: Financial Sector Returns and Creditor Moral Hazard: Evidence } \\
\text { from Indonesia, Korea and Thailand }\end{array}$ & $\begin{array}{l}\text { Ayse Y. Evrensel and Ali M. } \\
\text { Kutan }\end{array}$ & May 2004 \\
\hline $\begin{array}{l}\text { No. 686: Instability in Exchange Rates of the World Leading } \\
\text { Currencies: Implications of a Spatial Competition Model }\end{array}$ & $\begin{array}{l}\text { Dirk Engelmann, Jan Hanousek } \\
\text { and Evzen Kocenda }\end{array}$ & May 2004 \\
\hline $\begin{array}{l}\text { No. 685: Corporate Spinoffs, Privatization, and Performance in } \\
\text { Emerging Markets }\end{array}$ & $\begin{array}{l}\text { Jan Svejnar, Evzen Kocenda and } \\
\text { Jan Hanousekf }\end{array}$ & May 2004 \\
\hline $\begin{array}{l}\text { No. 684: CPI Bias and Real Living Standards in Russia During the } \\
\text { Transition }\end{array}$ & $\begin{array}{l}\text { John Gibson, Steven Stillman and } \\
\text { Trinh Le }\end{array}$ & May 2004 \\
\hline $\begin{array}{l}\text { No. 683: Mission Implausible III: Measuring the Informal Sector in a } \\
\text { Transition Economy using Macro Methods }\end{array}$ & Jan Hanousek and Filip Palda & May 2004 \\
\hline $\begin{array}{l}\text { No. 682: The Other Side of the Moon: The Data Problem in Analyzing } \\
\text { Growth Determinants }\end{array}$ & $\begin{array}{l}\text { Jan Hanousek, Dana Hajkova and } \\
\text { Randall K. Filer }\end{array}$ & May 2004 \\
\hline $\begin{array}{l}\text { No. 681: Consumers' Opinion of Inflation Bias Due to Quality } \\
\text { Improvements }\end{array}$ & $\begin{array}{l}\text { Jan Hanousek and Randall K. } \\
\text { Filer }\end{array}$ & May 2004 \\
\hline $\begin{array}{l}\text { No. 680: IMF-Related Announcements, Fundamentals, and Creditor } \\
\text { Moral Hazard: A Case Study of Indonesia }\end{array}$ & $\begin{array}{l}\text { Ayşe Y. Evrensel and Ali M. } \\
\text { Kutan }\end{array}$ & May 2004 \\
\hline No. 679: Privatization Matters: Bank Efficiency in Transition Countries & $\begin{array}{l}\text { John P. Bonin, Iftekhar Hasan and } \\
\text { Paul Wachtel }\end{array}$ & Apr. 2004 \\
\hline $\begin{array}{l}\text { No. 678: Does Market Liberalisation Reduce Gender Discrimination? } \\
\text { Econometric Evidence from Hungary, 1986-1998 }\end{array}$ & $\begin{array}{l}\text { Dean Jolliffe and Nauro F. } \\
\text { Campos }\end{array}$ & Apr. 2004 \\
\hline $\begin{array}{l}\text { No. 677: Governance and Performance of Microfinance Institutions in } \\
\text { Central And Eastern Europe and the Newly Independent States }\end{array}$ & Valentina Hartarska & Apr. 2004 \\
\hline $\begin{array}{l}\text { No. 676: Equilibrium Exchange Rates in the Transition: The Tradable } \\
\text { Price-Based Real Appreciation and Estimation Uncertainty }\end{array}$ & $\begin{array}{l}\text { Balázs Égert and Kirsten } \\
\text { Lommatzsch }\end{array}$ & Apr. 2004 \\
\hline $\begin{array}{l}\text { No. 675: Productivity growth and the real appreciation of the accession } \\
\text { countries' currencies }\end{array}$ & $\begin{array}{l}\text { Kirsten Lommatzsch and Silke } \\
\text { Tober }\end{array}$ & Apr. 2004 \\
\hline $\begin{array}{l}\text { No. 674: Exchange Rate Policy and Inflation in Acceding Countries: } \\
\text { The Role of Pass-through }\end{array}$ & $\begin{array}{l}\text { Fabrizio Coricelli, Boštjan Jazbec } \\
\text { and Igor Masten }\end{array}$ & Apr. 2004 \\
\hline No. 673: Is Kazakhstan a Market Economy Yet? Getting warmer.... & Sharon Eicher & Apr. 2004 \\
\hline $\begin{array}{l}\text { No. 672: Financial Institutions and The Wealth of Nations: Tales of } \\
\text { Development }\end{array}$ & Jian Tong and Chenggang $\mathrm{Xu}$ & Apr. 2004 \\
\hline $\begin{array}{l}\text { No. 671: Interest Rate Pass-Through in EU Acceding Countries: The } \\
\text { Case of the Czech Republic, Hungary and Poland }\end{array}$ & $\begin{array}{l}\text { Jesús Crespo Cuaresma, Balázs } \\
\text { Égert, and Thomas Reininger } \\
\end{array}$ & Mar. 2004 \\
\hline $\begin{array}{l}\text { No. 670: A minimum of rivalry: evidence from transition economies on } \\
\text { the importance of competition for innovation and growth }\end{array}$ & $\begin{array}{l}\text { Wendy Carlin, Mark Schaffer and } \\
\text { Paul Seabright }\end{array}$ & Mar. 2004 \\
\hline No. 669: Dual Track Liberalization: With and Without Losers & $\begin{array}{l}\text { Jiahua Che and Giovanni } \\
\text { Facchini }\end{array}$ & Mar. 2004 \\
\hline $\begin{array}{l}\text { No. 668: Enterprise Restructuring and Firm Performance: } \\
\text { A Comparison of Rural and Urban Enterprises in Jiangsu Province }\end{array}$ & $\begin{array}{l}\text { Xiao-yuan Dong, Louis } \\
\text { Putterman and Bulent Unel }\end{array}$ & Mar. 2004 \\
\hline $\begin{array}{l}\text { No. 667: A Tale of Two Provinces: The Institutional Environment and } \\
\text { Foreign Ownership in China }\end{array}$ & Yasheng Huang and Wenhua Di & Mar. 2004 \\
\hline $\begin{array}{l}\text { No. 666: Ownership Characteristics and Access to Finance: } \\
\text { Evidence from a Survey of Large Privatised Companies in Hungary } \\
\text { and Poland }\end{array}$ & $\begin{array}{l}\text { Natalia Isachenkova and Tomasz } \\
\text { Mickiewicz }\end{array}$ & Mar. 2004 \\
\hline
\end{tabular}

